\title{
Maternal Glucocorticoid Secretion Mediates Long-Term Effects of Prenatal Stress
}

\author{
Arnaud Barbazanges, Pier Vincenzo Piazza, Michel Le Moal, and Stefania Maccari \\ Psychobiologie des Comportements Adaptatifs, INSERM U259, Université de Bordeaux II, Domaine de Carreire, 33077 \\ Bordeaux Cedex, France
}

There is growing evidence that stressors occurring during pregnancy can impair biological and behavioral adaptation to stress in the adult offspring. Mechanisms by which stress in the pregnant rat can influence development of the offspring are still unknown. In the present study, we investigated the involvement of maternal corticosterone secretion during pregnancy on the hypothalamo-pituitary-adrenal axis activity of adult offspring. We investigated stress-induced corticosterone secretion and hippocampal type I and type II corticosteroid receptors in male adult rats submitted to prenatal stress born to either mothers with intact corticosterone secretion or mothers in which stressinduced corticosterone secretion was blocked by adrenalectomy with substitutive corticosterone therapy. Repeated restraint during the last week of pregnancy was used as prenatal stressor. Furthermore, the specific role of an injection of corticosterone before the restraint stress on adrenalectomized mothers with substitutive corticosterone treatment was also studied. We report here that blockade of the mother's stressinduced glucocorticoid secretion suppresses the prolonged stress-induced corticosteroid response and the decrease in type I hippocampal corticosteroid receptors usually observed in prenatally stressed adults. Conversely, corticosterone administered during stress, to mothers in which corticosterone secretion is blocked, reinstates the effects of prenatal stress. These results suggest for the first time that stress-induced incrcases in maternal glucocorticoids may be a mechanism by which prenatal stress impairs the development of the adult offspring's glucocorticoid response.

Key words: corticosterone; corticosteroid receptors; hippocampus; prenatal stress; maternal environment; development
Prenatal environments exert profound influences on the development of an organism and can predispose it to adaptive disturbances in later life. In particular, in man, prenatal stress can induce mental retardation and sleep disturbances in the infant (Stott, 1973; Shell, 1981). In animals, dams stressed during pregnancy can bear offspring with reduced male sexual activity, enhanced emotional reactivity (Thompson, 1957; Ward and Weisz, 1984; Weinstock et al., 1988), and an increased propensity to self-administer drugs (Deminière et al., 1992). Stress during pregnancy sensitizes different neuroendocrine systems, such as gonadal axis (Ward, 1972) and hypothalamo-pituitary-adrenal (HPA) axis, increasing stress-induced corticosterone secretion in preweaning rats (Peters, 1982; Takahashi et al., 1988; Henry et al., 1994) and prolonging stress-induced corticosterone secretion in the adult (Fride et al., 1986; Maccari et al., 1995). Prenatal stress also decreases the number of hippocampal corticosteroid receptors (Maccari et al., 1995), which are the principal substrate of the negative feedback control of glucocorticoid secretion. Thus, a decrease in these corticosteroid receptors is accompanied by increased glucocorticoid secretion and vice versa. Two different cytosolic receptors contribute to this control: (1) the type I, or mineralocorticoid receptor; and (2) the type II, or glucocorticoid receptor (McEwen et al., 1986; De Kloet and Reul, 1987). In the

\footnotetext{
Received Jan. 11, 1996; revised April 2, 1996; accepted April 3, 1996.

This work was supported by Institut National de la Santé et de la Recherche Médicalc. Université de Bordcaux II and Conseil Regional d'Aquitaine. We thank Dr. J. Day for helpful comments and Roussel-UCLAF for providing RU 28362.

Correspondence should be addressed to Stefania Maccari, Institut National de la Santé et de lá Rechurche Médicale U259, Université de Bordcaux II, Domaine de Carreire, Ruc Camille Saint Saens, 33077 Bordeaux Cedex, France.

Copyright 1 1996 Society for Neuroscience 0270-6474/96/163943-07\$05.00/0
}

adult, it has been shown that HPA axis disturbances are related to behavioral pathologies and early aging of cognitive performances (Sapolsky et al., 1986; Holsboer, 1989; Piazza et al., 1991).

In the present study, we addressed the following question: what are the pathophysiological mechanisms by which stress in the mother reaches the fetus and influences its development? One putative cause, in utero exposure to abnormally high levels of maternal glucocorticoids, seems to be a good candidate: (1) corticosterone secretion is one of the principal biological responses to stress (Selye, 1956); (2) glucocorticoids are very liposoluble and easily cross placental and blood-brain barriers (Zarrow et al., 1970); and (3) exposure in utero to high levels of synthetic glucocorticoids can have ncurotoxic effects on monkey and human brain (Epstein et al., 1977; Reinisch et al., 1978) or rat fetal brain (Uno et al., 1990) and elevate systolic blood pressure in adult offspring (Benediktsson et al., 1993).

To test this hypothesis, we studied the effects of blocking maternal corticosterone secretion during the prenatal stress on the stress-induced corticosterone secretion and hippocampal corticosteroid receptors of adult offspring. Repeated restraint of the mother during the last week of pregnancy was used as prenatal stressors, and an adrenalectomy of the mother with a corticosterone-substitutive treatment was used to block the increase in corticosterone secretion induced by the restraint stress. Hippocampal corticosteroid receptors were determined, as the binding capacity of these receptors appears to be a principal regulating factor in corticosterone secretion (McEwen et al., 1986; De Kloet and Reul, 1987). Furthermore, the specific role of an injection of corticosterone on stressed mothers adrenalectomized with corticosterone-substitutive treat- 
ment was also studied on these same parameters in adult offspring.

Our results show that the impairment induced by prenatal stress on the activity of the HPA axis of adult offspring depends on high levels of maternal corticosterone secretion during restraint stress. In fact, blocking stress-induced corticosterone secretion by adrenalectomy with corticosterone-substitutive treatment suppresses the prolonged stress-induced corticosterone response and the reduced type I hippocampal corticosteroid receptors observed in prenatally stressed adults. Furthermore, the administration of corticosterone to these mothers reinstates the effects induced by the prenatal stress.

\section{MATERIALS AND METHODS}

\section{General methods}

Subjects. Virgin female Wistar rats weighing $250 \mathrm{gm}$ were housed for $5 \mathrm{~d}$ in the presence of a sexually experienced Wistar male weighing 450-500 $\mathrm{gm}$. Pregnant females were individually housed with ad libitum access to food and water in a constant light/dark cycle (light on at $6 \mathrm{hr}$, off at $20 \mathrm{hr}$ ), and temperature $\left(22^{\circ} \mathrm{C}\right)$ and humidity $(60 \%)$ were kept constant.

Prenatal stress. During the last week of pregnancy, pregnant females in the stress group were placed for $45 \mathrm{~min}$ in a transparent plastic cylinder in a lighted environment three times per day (9 A.M., 12 A.M., and 5 P.M.). This stress procedure, described by Ward and Weisz (1984), was chosen because it has an indirect influence on the fetus via a direct stress on the mother. Control female rats were left undisturbed in their home cages. Only litters containing 10-14 pups were selected for this study to eliminate extra stressors such as the removal of pups. The offspring were weaned $21 \mathrm{~d}$ after birth, and 1-3 male siblings were taken from each litter. The number of litters represented in each group was 5-10. At the time of weaning, the sex of the pups was also checked, and only litters containing a similar number of females and males were selected. Animals were tested at $90 \mathrm{~d}$ of age.

Adrenalectomy and substitutive treatment. For this purpose, females at $13 \mathrm{~d}$ of pregnancy were adrenalectomized (between 9 A.M. and 12 A.M.) via the dorsal approach and implanted subcutaneously, $\sim 2 \mathrm{~cm}$ rostral to the skin incision, with a $100 \mathrm{mg}$ corticosterone pellet (containing $50 \%$ corticosterone 21 -hemisuccinate and $50 \%$ cholesterol), which provides stable basal levels of the hormone (Meyer et al., 1979). The adrenalectomy was performed under ether anesthesia. Pregnant females in the intact corticosterone secretion groups were sham-operated.

Corticosterone injection. The stressed mothers adrenalectomized with corticosterone-substitutive treatment received a subcutaneous injection of either saline $(\mathrm{NaCl} ; 0.9 \% \mathrm{w} / \mathrm{v})$ or corticosterone $(3 \mathrm{mg} / \mathrm{kg})$ concomitantly with stress. In a separate experiment, we showed that corticosterone injections in adrenalectomized pregnant rats elicit plasma corticosterone levels approximating those found in response to stress in intact mothers (Table 1)

Corticosterone assay. Corticosterone levels were determined in three blood samples $(250 \mu \mathrm{l})$ withdrawn from the tail vein before stress, after 30 min restraint stress, and $120 \mathrm{~min}$ afterward. Restraint was performed in plastic cylinders identical to those used for the prenatal stress. Blood was collected in heparinized tubes. Corticosterone levels were determined by radioimmunoassay using a highly specific corticosterone antiserum (ICN Biochemicals) with a detection threshold of $0.1 \mu \mathrm{g} / 100 \mathrm{ml}$. The inter- and intra-assay variations were, respectively, 6 and $3.5 \%$ at a mean value of $1.5 \mathrm{ng}$ per tube and 6.8 and $4 \%$ at a mean value of $10 \mathrm{ng}$ per tube.

Type I and type II corticosteroid receptor binding. Type I and type II hippocampal corticosteroid receptor binding was measured 2 weeks after the restraint stress procedure. Between 8:00 and 10:00 A.M., hippocampi were rapidly dissected and frozen on dry ice. Tissues were stored at $-80^{\circ} \mathrm{C}$ until receptor assay. To eliminate endogenous corticosterone, an exchange assay was used for both type I and type II corticosteroid receptors as described previously (Casolini et al., 1993; Maccari et al., 1995). The hippocampus of each rat was homogenized in $2 \mathrm{ml}$ of ice-cold $30 \mathrm{~mm}$ Tris (TEDGM; pH adjusted to 7.4 with $6 \mathrm{~N} \mathrm{HCl}$ ) containing $1 \mathrm{~mm}$ EDTA, $10 \mathrm{~mm}$ sodium molybdate, $1 \mathrm{~mm}$ dithiothreitol, and $10 \%$ glycerol, and centrifuged $(105,000 \mathrm{~g}, 15 \mathrm{~min}$ in a Beckman TL100 ultracentrifuge) at $4^{\circ} \mathrm{C}$. Endogenous, unbound steroids were removed from the soluble fraction by passing the sample through LH-20 columns filled using Pasteur pipette tips and equilibrated with TEGM buffer (10 mM Tris, 2 mM EDTA, $10 \mathrm{~mm}$ sodium molybdate, and $2.3 \mathrm{~mm} \beta$-mercaptoethanol). For the type I receptor assay, aliquots of cytosol $(140 \mu \mathrm{l})$ were incubated with tritiated corticosterone (specific activity $88 \mathrm{Ci} / \mathrm{mmol}$, DuPont NEN) over a concentration range of 1.25-40 nM (6 points for each Scatchard plot) and with a 100 -fold excess of unlabeled RU 28362. Unlabeled RU 28362 was used to displace ${ }^{3} \mathrm{H}-\mathrm{B}$ from type II receptors. Type II receptor binding was evaluated directly using the pure glucocorticoid, ${ }^{3} \mathrm{H}-\mathrm{RU}$ 28362 (specific activity $74.3 \mathrm{Ci} / \mathrm{mmol}$, Dositek) over a concentration range of 1.25-40 nM ( 6 points for each Scatchard plot). Nonspecific binding for ${ }^{3} \mathrm{H}-\mathrm{B}$ was determined in the presence of a 500 -fold excess of unlabeled corticosterone, and for ${ }^{3} \mathrm{H}-\mathrm{RU} 28362$ in the presence of a 500 -fold excess of unlabeled RU 28362. Binding equilibrium was reached after $22 \mathrm{hr}$ at $4^{\circ} \mathrm{C}$. This has been shown to be sufficient for maximal exchange, and binding remains stable over this period (Kalimi and Hubbard, 1983; Meaney et al., 1988). Although exchange may not be complete, it is comparable in all experimental groups. Bound and unbound ${ }^{3} \mathrm{H}-\mathrm{B}$ or ${ }^{3}$ H-RU 28362 were separated on Sephadex LH-20 columns equilibrated with TEGDM buffer at $2^{\circ} \mathrm{C}$, using $60 \mu$ l of the incubates eluted with 940 $\mu l$ of TEGDM buffer. One milliliter of the eluate containing the bound form was added to $3.5 \mathrm{ml}$ of scintillation fluid (Acqualuma, Lumac), and radioactivity was counted. Protein concentrations were determined according to Lowry et al. (1951) using albumin as standard. The apparent maximum binding capacity $\left(B_{\max }\right)$ of ${ }^{3} \mathrm{H}-\mathrm{B}$ or ${ }^{3} \mathrm{H}-\mathrm{RU} 28362$ and dissociation constants $\left(K_{d}\right)$ for both types of receptors were cvaluated from Scatchard plots (Scatchard, 1949) generated for each animal individually.

\section{Procedures}

Experiment 1: influence of blocking maternal corticosterone secretion during restraint stress on corticosterone and corticosteroid receptors of adult offspring. In this experiment, four groups of rat offspring were compared: two groups born to either control or stressed mothers with intact corticosterone secretion and two groups born to either control or stressed mothers in which stress-induced corticosterone secretion was blocked by adrenalectomy associated with a substitutive corticosterone treatment. At $90 \mathrm{~d}$ of age, offspring were submitted to a 30 min restraint stress. Restraint was performed in plastic cylinders identical to that used for the prenatal stress. Corticosterone levels were determined in three blood samples $(250 \mu \mathrm{l})$ withdrawn from the tail vein. The three samples were collected at the beginning and end of the $30 \mathrm{~min}$ stress and $120 \mathrm{~min}$ afterward. For the collection $120 \mathrm{~min}$ after the stress, the rat was again put in the restraint cage for $<2 \mathrm{~min}$. Type I and type II hippocampal corticosteroid receptor binding was measured 2 weeks later.

Experiment 2: influence of corticosterone injections during restraint stress to the mothers on corticosterone and corticosteroid receptors of adult offspring. In this experiment, to study the specific role of maternal corticosterone, four groups of rat offspring were compared: two groups were offspring of stressed mothers whose corticosterone secretion was either intact or blocked, and two groups were from stressed mothers having blocked corticosterone secretion, which received a subcutaneous injection of either saline $(\mathrm{NaCl} ; 0.9 \% \mathrm{w} / \mathrm{v})$ or corticosterone $(3$ $\mathrm{mg} / \mathrm{kg}$ ) concomitantly to stress. Also in this experiment, at $90 \mathrm{~d}$ of age, offspring were submitted to a 30 min restraint stress. Basal and stress

\section{Table 1. Plasma corticosterone concentrations after restraint stress in pregnant rats}

\begin{tabular}{|c|c|c|c|c|c|}
\hline \multirow[b]{2}{*}{$\begin{array}{l}\text { Time post } \\
\text { stress (min) }\end{array}$} & \multirow[b]{2}{*}{ Day 1} & \multicolumn{2}{|c|}{ Plasma corticosterone $(\mu \mathrm{g} / 100 \mathrm{ml})$} & \multirow[b]{2}{*}{ Blocked + corticosterone } & \multirow[b]{2}{*}{ Day 5} \\
\hline & & $\begin{array}{l}\text { Intact } \\
\text { Day } 5\end{array}$ & Day 7 & & \\
\hline $30 \mathrm{~min}$ & $58.6 \pm 3.8$ & $74.1 \pm 7.5$ & $59.9 \pm 4.2$ & $82.9 \pm 13.0$ & $95.5 \pm 23.5$ \\
\hline $105 \mathrm{~min}$ & $42.7 \pm 3.7^{*}$ & $33.4 \pm 10.7^{*}$ & $25.2 \pm 7.6^{*}$ & $33.0 \pm 1.6^{*}$ & $9.6 \pm 1.9^{* \#}$ \\
\hline
\end{tabular}




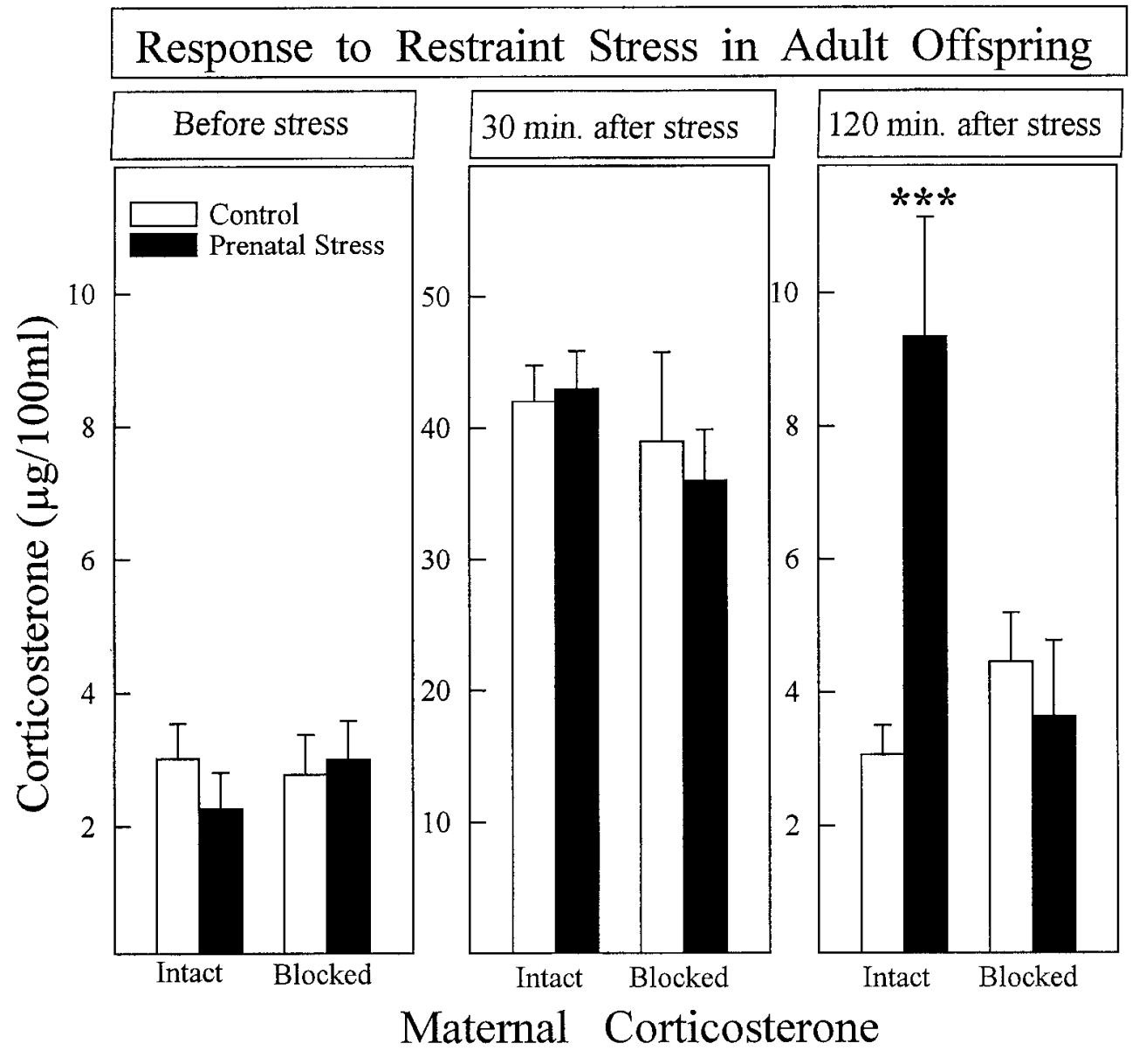

Figure 1. Plasma corticosterone secretion after restraint stress in control and prenatally stressed offspring of mothers with intact (14-20 inimals/group) or blocked (7-10 animals/group) stressinduced corticosterone secretion. The experimental groups did not differ in corticosterone secretion in basal conditions (left panel) or 30 min after stress (middle panel). At 120 min after stress (right pan$e l$ ), prenatally stressed animals, the mothers of which were in the intact group, had higher corticosterone levels than controls. Prenatally stressed rats whose mothers' corticosterone secretion was blocked did not differ from controls. ${ }^{* * *} p<0.001$. Error bars represent SEM. corticosterone levels were determined as described previously. Type I and type II hippocampal corticosteroid receptor binding was measured 2 weeks later.

Statistics. The results were compared by two-way bifactorial analysis (ANOVA). In the first experiment, the two between factors were: (1) stress (two levels, presence/absence); and (2) maternal corticosterone (two levels, intact/blocked). In the second experiment, the two between factors were: (1) corticosterone (two levels, high/low); and (2) subcutaneous injection (two levels, presence/absence).

\section{RESULTS}

\section{Experiment 1. Influence of blocking maternal corticosterone secretion during restraint stress on stress-induced corticosterone secretion and hippocampal corticosteroid receptors of adult offspring}

At 3 months of age, offspring of stressed mothers whose corticosterone secretion was intact showed a prolonged stress-induced corticosterone secretion (Fig. 1) and decreased hippocampal type I corticosterone receptors (Fig. 2). Type I and type II hippocampal corticosteroid receptor binding had been measured 2 weeks after the restraint stress procedure, and the hippocampi were dissected between 8:00 and 10:00 A.M. In contrast, offspring of stressed mothers whose corticosterone secretion was blocked did not differ from rats of control mothers for any of the parameters studied. A bifactorial analysis was used, and the two between factors were: (1) stress (presence/absence); (2) maternal corticosterone (Intact/blocked). The following main effects and interactions were significant: (1) stress-induced corticosterone secretion $\left[\right.$ Stress $\times$ Maternal Corticosterone $\times$ Time Interaction; $F_{(2,92)}=$
4.997; $p=0.008$ ]; (2) corticosterone 2 hr after stress [Stress $\times$ Maternal Corticosterone Interaction; $\left.F_{(1,46)}=8.34 ; p=0.006\right]$; and (3) type I receptors [Stress $\times$ Maternal Corticosterone Interaction; $\left.F_{(1,45)}=14.46 ; p=0.0005\right]$.

\section{Experiment 2. Influence of high levels of maternal corticosterone during restraint stress on stress- induced corticosterone secretion and hippocampal corticosteroid receptors of adult offspring}

Offspring of mothers in which corticosterone levels were high during stress had a longer stress-induced corticosterone secretion (Fig. 3) and lower hippocampal type I corticosteroid receptors (Fig. 4) than animals whose mothers had low corticosterone levels. The two between factors were: (1) corticosterone (high/ low); (2) subcutaneous Injection (presence/absence). The following main effects and interactions were significant: (1) stressinduced corticosterone secretion [Corticosterone $\times$ Time Interaction; $\left.F_{(2,78)}=8.308 ; p=0.000 .5\right]$; (2) corticosterone levels $2 \mathrm{hr}$ after stress [Corticosterone Effect; $F_{(1,39)}=11.342 ; p=$ $0.0018]$; (3) type I corticosterone receptors in the hippocampus [Corticosterone Effect; $F_{(1,31)}=12.38 ; p=0.0015$ ]. Because the injection itself had no effect and no significant interaction was found between the two main factors in Figs. 3 and 4, results were collapsed over the injection factor.

\section{DISCUSSION}

Taken together, these results suggest that disruption of the hormonal response to stress observed in prenatally stressed individ- 


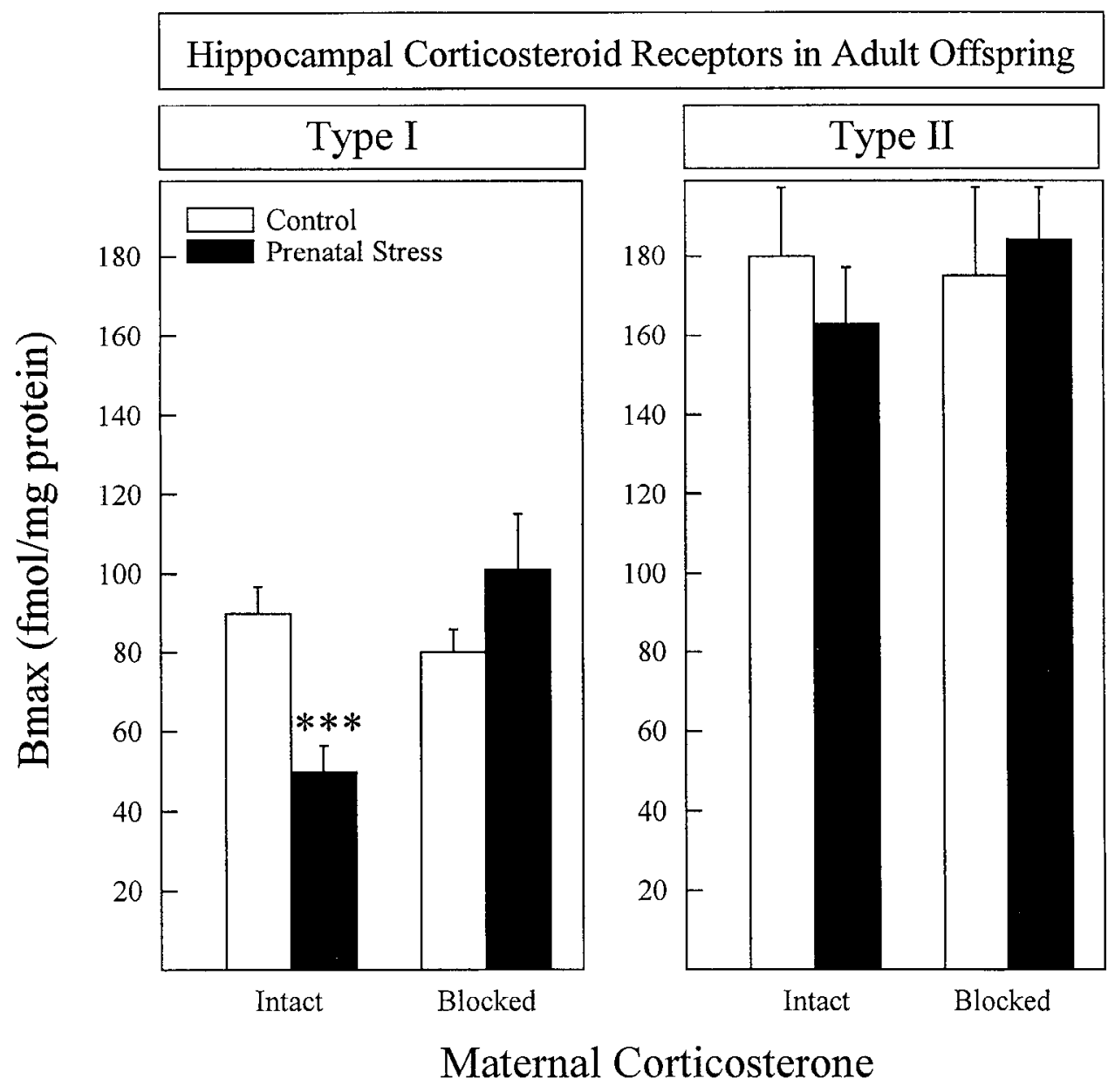

uals depends on stress-induced increases in maternal glucocorticoids. The characteristic impairment of HPA axis activity normally seen in prenatally stressed rats was suppressed by blocking the mother's stress-induced corticosterone secretion, using adrenalectomy associated with a corticosterone replacement treatment. Conversely, the effects of prenatal stress were reinstated by peripheral administration of corticosterone (at doses mimicking stress levels) to these mothers.

The present findings are in agreement with data showing that exposure of pregnant rats to alcohol, a procedure that stimulates maternal glucocorticoid secretion, results in a hyperactive HPA axis in the offspring (Rivier et al., 1984; Lee et al., 1990). However, exogenous prenatal corticosterone replacement did not have the same effect as prenatal ethanol exposure (Lee and Rivier, 1992), probably because the corticosterone replacement was made from days 8 to 14 of gestation and the fetal HPA axis is not functional until the middle of the third week of gestation (Bugnon et al., 1982). Similarly, nonabortive maternal infections, which increase maternal glucocorticoids (Besedovsky et al., 1975; Dunn, 1992), compromise the development of the fetal brain and alter HPA axis functioning in the adult (Reul et al., 1994). However, maternal factors other than corticosterone can also contribute to longterm HPA reactivity in the adult male offspring. Thus, we have previously shown that the increased postnatal maternal care induced by an early adoption reverses the long-term effects on HPA reactivity induced by prenatal stress (Maccari et al., 1995).

Of the many actions of maternal glucocorticoids during development, at least two may account for the observed effects on the offspring's HPA axis. (1) High glucocorticoid levels may alter the HPA axis development by downregulating fetal hippocampal corticosteroid receptors, which are already fully expressed during the last week of gestation (Meaney et al., 1985; Rosenfeld et al., 1988). (2) High glucocorticoid levels may modify glucocorticoid secretion in the offspring by acting on the developing noradrenergic systems. Indeed, prenatal stress is known to increase the turnover of brain norepinephrine in adult rats (Takahashi et al., 1992), and norepinephrine exerts a direct inhibitory control on hippocampal corticosteroid receptors, thus facilitating corticosterone secretion (Maccari et al., 1992; Yau and Seckl, 1992).

The decrease in hippocampal type I corticosteroid receptors observed in prenatally stressed rats could account for their prolonged stress-induced corticosterone secretion. Hippocampal corticosteroid receptors appear to play an important role in this process, as it has been shown that a selective reduction in hippocampal corticosteroid receptors is accompanied by a prolonged corticosterone secretion in response to stress (McEwen et al., 1986; Sapolsky et al., 1986). In view of their affinities for corticosterone, it is generally thought that type II receptors are involved in stress-induced feedback mechanisms, whereas type I receptors are involved in the tonic regulation of corticosterone release under basal conditions (De Kloet and Reul, 1987). Thus, in the present study, the observed decrease in hippocampal type I receptors might not be expected to be involved in stress-modulated feedback control. However, there is now evidence that both receptor types are involved in feedback control mechanisms. The administration of type I antagonists induces prolonged adreno- 


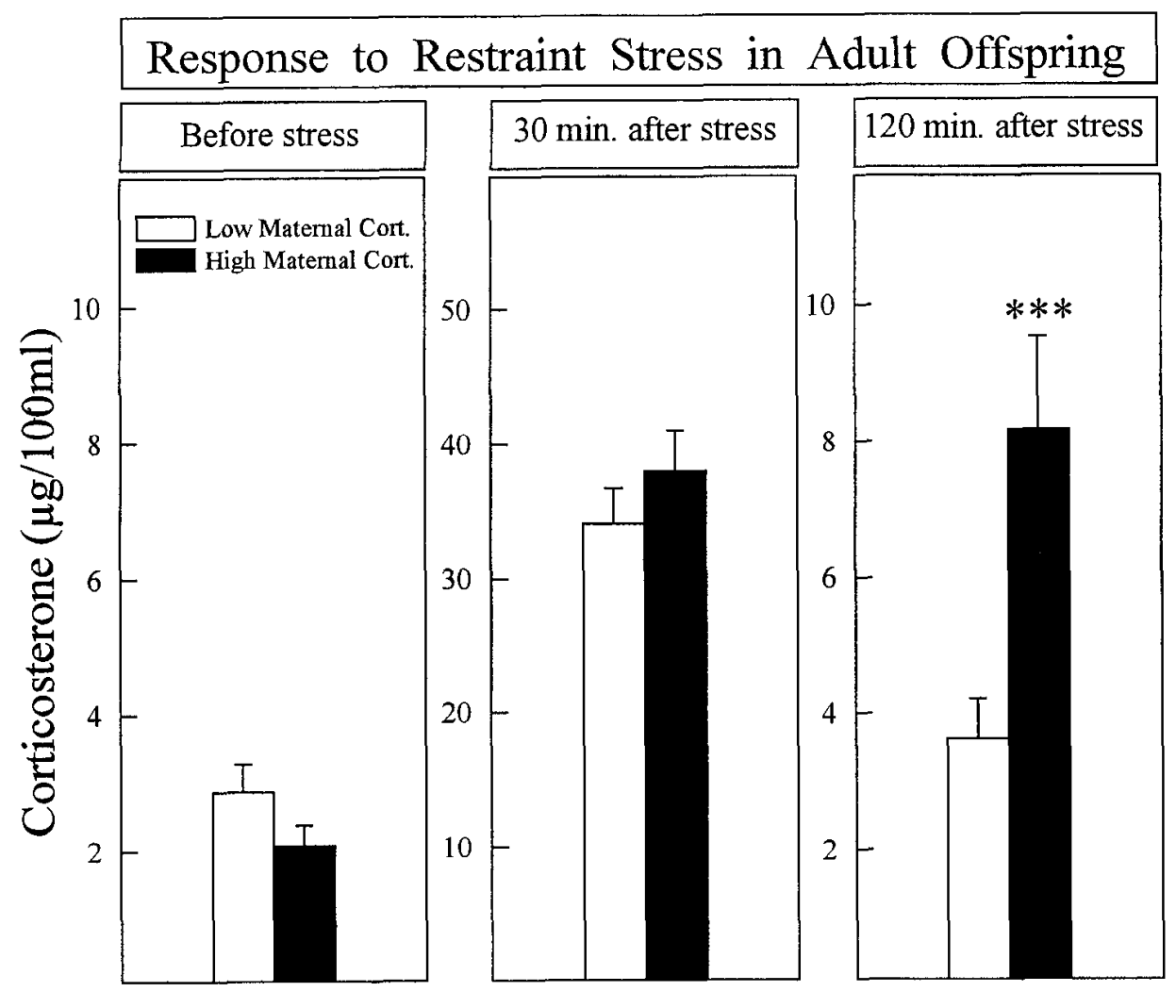

Maternal Corticosterone

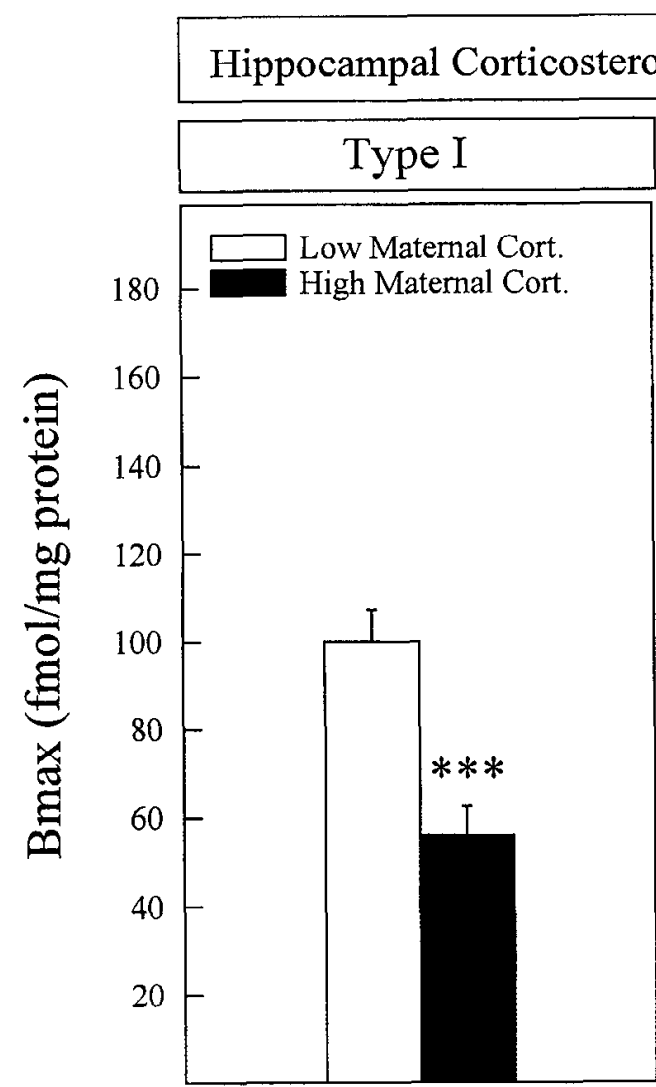

Figure 3. Plasma corticosterone secretion after restraint stress in prenataily stressed rats, the mothers of which had either low (5-10 animals/group) or high (10-14 animals/group) corticosterone lcvels when submitted to stress during pregnancy. There were no significant differences in corticosterone secretion in basal conditions (left panel) or $30 \mathrm{~min}$ after stress (middle panel), whereas prenatally stressed rats from mothers having high corticosterone levels had a prolonged stress-induced corticosterone secretion (right panel). ${ }^{* *} p<0.001$. Error bars represent SEM.
Figure 4. Hippocampal corticosteroid receptors in rats, the mothers of which had cither low (5-10 animals/group) or high (10-14 animals/group) corticosterone levels when submitted to stress during pregnancy. Type I corticosteroid receptors were lower in animals from mothers having high corticosterone levels (left panel). No differences were found in the $B_{\max }$ of type II receptors (right panel) or in the affinities of either receptor type. Mean affinities were (in nM): type $\mathrm{I}=1.71 \pm 0.15 ;$ type II $=1.56 \pm 0.30$. ${ }_{* * *} p<0.001$. Error bars represent SEM. 
cortical secretion after stress (Ratka et al., 1989), and the occupancy of both types of receptors in the hippocampus by corticosterone is required for the feedback suppression of corticotropinreleasing factor secretion during stress (Sapolsky et al., 1990). In addition, Dallman et al. (1989) suggested that the effect of corticosterone on basal adrenocorticotropic hormone secretion is mediated by association with type I receptors, and not type II. This idea is also supported by two further observations. First, an early adoption, which suppresses the prolonged corticosterone secretion in prenatally stressed animals, also increases type I receptors in the hippocampus (Maccari et al., 1995). Second, a selective reduction in type I hippocampal corticosteroid receptors has been found to be associated with a prolonged stress-induced corticosterone secretion in chronically social stressed animals, akin to that observed in prenatally stressed rats (Maccari et al., 1991).

It should be noted that the assay used to measure the abovementioned changes in corticosteroid receptors was an exchange assay for both type I and type II corticosteroid receptors to eliminate endogenous corticosterone as described previously (Kalimi and Hubbard, 1983; Meaney et al., 1988; Casolini et al., 1993; Maccari et al., 1995). It is important to consider that although exchange may not be complete, it is comparable in all experimental groups given that the corticosterone concentrations in the different groups of rats at the time of killing were at their basal levels and, thus, essentially the same across treatment groups. It can therefore be assumed that the decrease in type I corticosteroid receptors was not attributable to a different occupancy of this type of receptor by corticosterone. However, future studies should address whether the mRNA for the type I receptor is also lower in these animals.

There is strong cvidence indicating that increased corticosterone levels in prenatal and postnatal life have opposite effects on adult corticosterone secretion. Thus, in contrast to the present results, corticosterone secretion is reduced in adult rats that have received corticosterone during the first week after birth (Turner and Taylor, 1976; Catalani et al., 1993). Although seemingly contradictory, these profound differences in corticosterone's effects in the prenatal versus pustnatal period might be explained by a difference in the maturational status of hippocampal corticosteroid receptors in fetus versus pup. During the last week of fetal life, levels of corticosteroid receptors are similar to those in adults, whereas at birth their number is profoundly decreased, increasing again only at 12-14 d of age (Meaney et al., 1985; Rosenfeld et al., 1988).

In conclusion, the present report clearly shows the major influence of maternal glucocorticoids on the development of endocrinc function in the offspring. Our results suggest that the high level of maternal glucocorticoids during prenatal stress, when the fetal HPA axis is developing, has marked long-term repercussions on the efficiency of the offspring's HPA negative feedback mechanisms. Furthermore, given the influence of maternal glucocorticoids on brain development, the antenatal glucocorticoid treatment currently used for reducing the frequency of respiratory distress syndrome and neonalal death (Farrell and Nilzan, 1979; Ballard et al., 1980; National Institutes of Health Consensus Statement, 1994) may not be without negative long-term side effects.

\section{REFERENCES}

Ballard PL, Gluckman PD, Liggins GC, Kaplan SL, Grumbach MM (1980) Steroid and growth hormone levels in premature infants after prenatal betamethasone therapy to prevent respiratory distress syndrome. Pediatr Res 14:122-127.
Benediktsson R, Lindsay RS, Noble J, Seckl JR, Edwards CRW (1993) Glucocorticoid exposure in utero: new model for adult hypertension. Lancet 341:339-341.

Besedovsky HO, Sorkin F, Keller M, Muller I (1975) Change in blood hormone levels during the immune response. Proc Soc Exp Biol Med 150:466-470.

Bugnon C, Fellmann D, Gouget A, Cardot J (1982) Ontogeny of the corticoliberin neuroglandular system in rat brain. Nature 298:159-161.

Casolini P, Piazza PV, Kabbaj M, Leprat F, Angelucci L, Simon H, Le Moal M (1993) The mesolimbic dopaminergic system exerts an inhibitory influence on brain corticosteroid receptor affinities. Neuroscience 55:429-434.

Catalani A, Marinelli M, Scaccianoce S, Nicolai R, Muscolo LAA, Porcu A, Koranyi L, Piazza PV, Angelucci L (1993) Progeny of mother drinking corticosterone during lactation has lower stress-induced corticosterone secretion and better cognitive performance. Brain Res 624:209-215

Dallman MF, Levin N, Cascio CS, Akana SF, Jacobson L, Kuhn RW (1989) Pharmacological evidence that the inhibition of diurnal adrenocorticotropin secretion by corticosteroids is mediated via type I corticosterone-preferring receptors. Endocrinology 124:2844-2850.

De Kloet ER, Reul JMHM (1987) Feedback action and tonic influence of corticosteroids on brain function: a concept arising from the heterogeneity of brain receptor systems. Psychoneuroendocrinology 12:83-105.

Deminière JM, Piazza PV, Guegan G, Abrous N, Maccari S, Le Moal M, Simon H (1992) Increased locomotor response to novelty and propensity to intravenous amphetamine self-administration in adult offspring of stressed mothers. Brain Res 586:135-139.

Dunn A (1992) Endotoxin-induced activation of cerebral catecholamine and serotonin metabolism: comparison with interleukin-1. J Pharmacol Exp Ther 261:964-969.

Epstein MF, Farrell PM, Sparks JW, Pepe G, Driscoll SG, Chez RA (1977) Maternal betamethasone and fetal growth and development in the monkey. Am J Obstet Gynecol 127:261-263.

Farrell PM, Nitzan M (1979) The effects of adrenal corticosteroids on the fetus with particular reference to fetal lung maturation. Pediatr Adolesc Endocrinol 5:88-109.

Fride E, Dan Y, Feldon J, Halevy G, Weinstock M (1986) Effects of prenatal stress on vulnerability to stress in prepubertal and adult rats. Physiol Behav 37:681-687.

Henry C, Kabbaj M, Simon H, Le Moal M, Maccari S (1994) Prenatal strcss incrcascs the hypothalamo-pituitary-adrenal axis response in young and adult rats. J Neuroendocrinology 6:341-345.

Holsboer F (1989) Psychiatric implications of altered limbichypothalamic-pituitary-adrenocortical activity. Eur Arch Psychiatry Neurol Sci 238:302-322

Kalimi M, Hubbard JR (1983) Development of an exchange assay for cytosolic glucocorticoid receptors using the synergistic effects of molybdate plus dithiothreitol. Endocrinology 113:1161-1163.

Lee S, Rivier C (1992) Administration of corticosterone to pregnant adrenalectomized dams does not alter the hypothalamic-pituitaryadrenal axis' activity of the offspring. Mol Cell Neurosci 3:118-123.

Lee S, Imaki T, Vale W, Rivier C (1990) Effect of prenatal exposure to ethanol on the activity of the hypothalamic-pituitary-adrenal axis of the offspring: importance of the time of exposure to ethanol and possible modulating mechanisms. Mol Cell Neurosci 1:168-177.

Lowry OH, Rosenbough N, Farr AL, Randall RJ (1951) Protein measurements with the Folin phenol reagent. J Biol Chem 193:265-267.

Maccari S, Piazza PV, Deminière JM, Lemaire V, Mormède P, Simon H, Angelucci L, Le Moal M (1991) Life events-induced decrease of corticosteroid type I receptors is associated with reduced corticosterone feedback and enhanced vulnerability to amphetamine selfadministration. Brain Res 547:7-12.

Maccari S, Mormède P, Piazza PV, Simon H, Angelucci L, Le Moal M (1992) Hippocampal type I and type II corticosteroid receptors are modulated by central noradrenergic systems. Psychoneuroendocrinology 17:103-112.

Maccari S, Piazza PV, Kabbaj M, Barbazanges A, Simon H, Le Moal M (1995) Adoption reverses the long-term impairment in glucocorticoid feedback induced by prenatal stress. J Neurosci 15:110-116.

McEwen BS, De Kloet ER, Rostène W (1986) Adrenal steroid receptors and actions in the nervous system. Physiol Rev 66:1121-1188.

Meaney MJ, Sapolsky RM, Aitken DH, McEwen BS (1985) [ $\left.{ }^{3} \mathrm{H}\right]$ dexamethasone binding in fetal rat limbic brain. Dev Brain Res 23:297-300. 
Meaney MJ, Viau V, Aitken DH, Bhatnagar S (1988) Stress-induced occupancy and translocation of hippocampal glucocorticoid receptors. Brain Res 445:198-203.

Meyer JS, Micco DJ, Stephenson BS, Krey LC, McEwen BS (1979) Subcutaneous implantation method for chronic glucocorticoid replacement therapy. Physiol Behav 22:867-870.

National Institutes of Health Consensus Statement (1994) Effect of corticosteroids for fetal maturation on perinatal outcomes, pp 1-24.

Peters DAV (1982) Prenatal stress: effects on brain biogenic amine and plasma corticosterone levels. Pharmacol Biochem Behav 17:721-725.

Piazza PV, Maccari S, Deminière JM, Le Moal M, Mormède P, Simon H (1991) Corlicusteronte levels determine individual vulnerability to amphetamine self-administration. Proc Natl Acad Sci USA 88:2088-2092.

Ratka A, Sutanto W, Bloemers M, De Kloet ER (1989) On the role of brain mineralocorticoid (Type I) and glucocorticoid (Type II) receptors in neuroendocrine regulation. Neuroendocrinology 50:117-123.

Reinisch JM, Simon NG, Karow WG, Gandelman R (1978) Prenatal exposure to prednisone in humans and animals retards intrauterine growth. Science 202:436-438.

Reul JMHM, Stec I, Wiegers GJ, I abeur MS, Linthorst ACE, Arzt E, Holsboer F (1994) Prenatal immune challenge alters the hypothalamic-pituitary-adrenocortical axis in adult rats. $\mathrm{J}$ Clin Invest 93:2600-2607.

Rivier C, Bruhn T, Vale W (1984) Effect of ethanol on the hypothalamicpituitary-adrenal axis in the rat: role of corticotrophin-releasing factor (CRF). J Pharmacol Exp Ther 229:127-131.

Rosenfeld P, Sutanto W, Levine S, De Kloet ER (1988) Ontogeny of type I and type II corticosteroid receptors in the rat hippocampus. Dev Brain Res 42:113-138.

Sapolsky RM, Krey LC and McEwen BS (1986) The neuroendocrinology of stress and aging: the glucocorticoid cascade hypothesis. Endocr Rev 7:24-301.

Sapolsky RM, Armanini MP, Packan DR, Sutton WS, Plotsky PM (1990) Glucocorticoid feedback inhibition of adrenocorticotropic hormone secretagogue release. Neuroendocrinology 51:328-336.
Scatchard G (1949) The attraction of proteins for small molecules and ions. Ann N Y Acad Sci 51:660.

Selye H (1956) The stress of life. New York: McGraw-Hill.

Shell LM (1981) Environmental noise and human prenatal growth. Am J Physiol Anthropol 56:63-70.

Stott DN, (1973) Follow-up study from birth of the effects of prenatal stress. Dev Med Child Neurol 15:770-787.

Takahashi LK, Kalin NH, Barksdale CM, Van Der Burgt JA (1988) Stressor controllability during pregnancy influcnecs pituitary-adrenal hormone concentrations and analgesic responsiveness in offspring. Physiol Behav 42:323-329.

Takahashi LK, Turner JG, Kalin NH (1992) Prenatal stress alters brain catecholaminergic activity and potentiates stress-induced behavior in adult rats. Brain Res 574:131-137.

Thompson WR (1957) Influence of prenatal maternal anxiety on emotionality in young rats. Science 125:698-699.

Turner BB, Taylor AN (1976) Persistent alteration of pituitary-adrenal function in the rat by prepuberal corticosterone treatment. Endocrinology $98: 1-9$.

Uno H, Long L, Thieme C, Kemnitz JW, Engle MJ, Roecker EB, Farrell PM (1990) Brain damage induced by prenatal exposure to dexamethasone in fetal rhesus macaques. I. Hippocampus. Dev Brain Res 53:157-167.

Ward IL (1972) Prenatal stress feminizes and demasculinizes the behavior of males. Science 175:82.

Ward IL, Weisz J (1984) Differential effects of maternal stress on circulating levels of corticosterone, progesterone and testosterone in male and female rat fetus and their mothers. Endocrinology 84:1635-1644.

WeinstocK M, Fride E, Hertzberg R (1988) Prenatal stress effects on functional development of the offspring. Prog Brain Res 73:319-331.

Yau JLW, Seckl JR (1992) Central 6-hydroxydopamine lesions decrease mineralocorticoid, but not glucocorticoid receptor gene expression in the rat hippocampus. Neurosci Lett 142:159-162.

Zarrow MX, Philpott JE, Denenberg VH (1970) Passage of 14C-4 Corticosterone from the rat mother to the foetus and neonate. Nature 226:1058-1059. 